\title{
DETERMINANT OF EFFICIENCY OF THE ISLAMIC BANKING IN INDONESIA
}

\author{
Nadiah Hidayati', Hermanto Siregar', Syamsul Hidayat Pasaribu
}

\begin{abstract}
Dual banking system in Indonesia provides an excellent opportunity for the growth of Islamic banking industry in Indonesia. Islamic banking industry in Indonesia has improved in number of banks and branches but the performance of Islamic banks has decreased in recent years. This paper measures the efficiency of Islamic banking in Indonesia using the intermediation approach and the Data Envelopment Analysis (DEA) on quarterly reports of 10 Islamic Banks (BUS) and 15 Islamic Business Units (UUS). The results showed that Islamic Banks (BUS) and Islamic Business Units (UUS) in Indonesia has not been operating efficiently in its intermediation function. The estimation results of data panel regression model showed total financing and CAR have positive and significant impact, whereas the deposits have negative and significant impact to the efficiency of BUS and UUS in Indonesia.
\end{abstract}

Keywords: Data panel, DEA, efficiency, Indonesia, Islamic banking

JEL Classification: C63, G14, G21

1 Nadiah Hidayati; corresponding author, (nadiahhidayati@yahoo.com) is a post graduate student at School of Business, Bogor Agricultural University (IPB).

2 Hermanto Siregar (hermanto@mma.ipb.ac.id, hermantosiregar@yahoo.com) and Syamsul Hidayat Pasaribu (syamsulhp@gmail. com) are lecturers at School of Business, Bogor Agricultural University (IPB) 


\section{PENDAHULUAN}

Sektor perbankan memegang peranan yang cukup penting bagi perekonomian Indonesia. Penetapan UU No 21 tahun 2008 mengenai perbankan syariah memperkuat eksistensi bank syariah di Indonesia. Undang-undang tersebut mengatur segala sesuatu mengenai kelembagaan, kegiatan usaha, serta cara dan proses dalam melaksanakan kegiatan usaha bank syariah. Undang-undang tersebut memberikan landasan hukum yang kuat bagi Bank Indonesia untuk melakukan pengaturan dan pengawasan terhadap perbankan syariah. Hal ini memberikan peluang yang sangat baik bagi tumbuhnya industri perbankan syariah di Indonesia.

Perbankan syariah di Indonesia telah mengalami pertumbuhan dalam hal kelembagaan. Menurut laporan Otoritas Jasa Keuangan, sampai dengan Juli 2016 tercatat sudah 12 Bank Umum Syariah (BUS), 22 Unit Usaha Syariah (UUS), dan 103 Bank Pembiayaan Rakyat Syariah (BPRS) yang tersebar di hampir seluruh wilayah Indonesia. Peningkatan jumlah bank dan kantor dari tahun ke tahun ini memberikan dampak positif bagi perkembangan industri perbankan syariah. Hal ini dapat dilihat dari nilai total aset, Dana Pihak Ketiga (DPK), dan pembiayaan yang meningkat selama tiga tahun terakhir.

\begin{tabular}{|c|c|c|c|}
\hline \multicolumn{4}{|c|}{$\begin{array}{c}\text { Tabel } 1 . \\
\text { Perkembangan Indikator Keuangan BUS dan UUS tahun 2013-2015 }\end{array}$} \\
\hline Indikator & 2013 & 2014 & 2015 \\
\hline Total Aset (milyar rupiah) & 242.276 & 272.343 & 296.262 \\
\hline Growth (persen) & 24 & 12 & 8,78 \\
\hline DPK (milyar rupiah) & 183.534 & 217.858 & 231.175 \\
\hline Growth (persen) & 29 & 19 & 6,11 \\
\hline Pembiayaan (milyar rupiah) & 184.120 & 199.330 & 212.996 \\
\hline Growth (persen) & 32 & 8 & 7 \\
\hline Sumber: Otoritas Jasa Keuangan, 2016 & & & \\
\hline
\end{tabular}

Pada Tabel 1 dapat dilihat bahwa nominal total aset, penghimpunan DPK, dan pembiayaan yang disalurkan bank syariah dan unit usaha syariah meningkat tiap tahunnya. Laju pertumbuhan aset perbankan syariah selama ini ditopang pertumbuhan DPK, sehingga kemampuan perbankan syariah dalam penghimpunan DPK sangat menentukan akselerasi pertumbuhan asetnya. Tabel diatas juga menjelaskan terjadinya perlambatan pertumbuhan sejak tahun 2013 disemua indikator keuangan BUS dan UUS.

Kinerja BUS dan UUS juga dapat dilihat melalui beberapa rasio keuangan seperti Non Performing Financing (NPF) dan Financing Deposit Ratio (FDR). Selama tiga tahun terakhir, BUS dan UUS mengalami penurunan kinerja. Hal ini dapat dilihat dari meningkatnya nilai NPF dan menurunnya nilai FDR. Hal ini mengindikasikan kinerja perbankan syariah masih belum berjalan secara optimal (Grafik 1). 


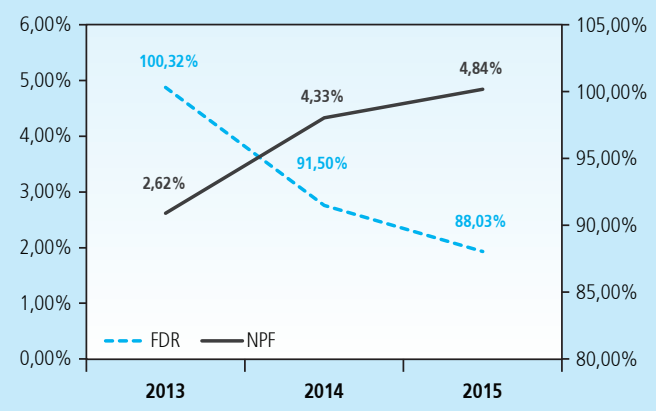

Grafik 1. Kinerja BUS dan UUS tahun 2013-2015

Tren nilai rasio NPF yang meningkat menjelaskan bahwa semakin besarnya risiko pembiayaan perbankan syariah. Hal ini disebabkan meningkatnya pembiayaan bermasalah pada BUS dan UUS. Kemampuan bank menjalankan fungsi intermediasinya terlihat dari nilai rasio FDR. Penurunan nilai rasio FDR mengimplikasikan pembiayaan yang disalurkan bank syariah mengalami penurunan (Gambar 1). Hal ini mengindikasikan kinerja perbankan syariah masih belum berjalan secara optimal.

Bank syariah sebagai salah satu lembaga keuangan perlu menjaga kinerjanya agar dapat beroperasi secara optimal. Kinerja tersebut dapat dilihat melalui Tingkat Kesehatan Bank (TKS Bank) yang harus dipelihara dan/atau ditingkatkan agar kepercayaan masyarakat terhadap bank dapat tetap terjaga. Selain itu, TKS bank digunakan sebagai salah satu sarana dalam melakukan evaluasi terhadap kondisi dan permasalahan yang dihadapi bank. TKS adalah hasil penilaian kondisi bank yang dilakukan terhadap risiko dan kinerja bank. Bank wajib memelihara dan/atau meningkatkan TKS dengan menerapkan prinsip kehati-hatian dan manajemen risiko dalam melaksanakan kegiatan usaha. Penilaian TKS bank dapat dilakukan dengan menganalisa laporan keuangan bank yang bersangkutan. Berdasarkan laporan keuangan tersebut dapat diperoleh adanya suatu informasi mengenai aliran kas dan informasi lain yang berkaitan dengan kinerja bank.

Efisiensi merupakan gambaran kinerja suatu perusahaan dan menjadi aspek penting untuk mewujudkan suatu kinerja keuangan yang sehat dan berkelanjutan. Efisiensi bank menjadi salah satu indikator untuk menganalisa kinerja (performance) suatu bank. Menurut Wheelock dan Wilson (1999), efisiensi adalah ukuran penting dari kondisi operasional bank dan merupakan salah satu kunci indikator kesuksesan suatu bank.

Penilaian efisiensi bank dibutuhkan agar bank dapat bertindak rasional dalam meminimumkan tingkat risiko yang dihadapi dalam menjalani kegiatan operasionalnya. Hal ini dilakukan agar bank syariah mempunyai daya saing yang tinggi dalam industri perbankan 
nasional dan dapat memperluas pangsa pasarnya (market share). Sejalan dengan hal itu, Muharam dan Pusvitasari (2007) menjelaskan bahwa analisa efisiensi bank syariah penting untuk dilakukan karena penghimpunan dan penyaluran pembiayaan yang ekspansif tanpa memperhatikan faktor efisiensi akan berpengaruh terhadap profitabilitas suatu bank.

Menurut Berger dan Humphrey (1992), pembuatan skor efisiensi tidak bisa dilakukan secara parsial seperti pengukuran biaya operasional dengan pendapatan operasional, tetapi harus memperhitungkan seluruh output dan seluruh input yang ada. Hal ini juga diperkuat oleh Mansyur (2012) yang menyatakan bahwa pengukuran efisiensi bank dihadapkan pada kondisi bagaimana mendapatkan tingkat output yang optimal dengan tingkat output yang ada, atau mendapatkan tingkat input yang minimum dengan tingkat output tertentu, sehingga penyebab ketidakefisienan dapat dianalisa lebih jauh. Dengan demikian, pendekatan yang lebih tepat dalam pengukuran kinerja efisiensi adalah dengan menggunakan pendekatan frontier berupa analisa parametrik dan non-parametrik. Hasil studi menunjukkan pengukuran efisiensi yang dilakukan dengan non-parametrik maupun parametrik akan menunjukkan hasil yang tidak terlalu jauh berbeda dan relatif konsisten (Hadad et al. 2003; Abidin dan Cabanda 2007).

Bagian kedua dari paper ini mengulas teori dan literatur yang terkait. Bagian ketiga mengulas data dan metodologi, sementara hasil dan analisisnya disajikan pada bagian keempat. Bagian lima menyajikan kesimpulan dan implikasi penelitian dan menjadi bagian penutup dari paper ini.

\section{TEORI}

Pengertian bank syariah ialah bank yang operasional dan produknya dikembangkan berlandaskan prinsip-prinsip syariah Islam yaitu Al-Qur'an dan Al-Hadist. Menurut Antonio (2001), bank syariah adalah bank yang menjalankan operasionalnya mengikuti ketentuan-ketentuan syariah Islam khususnya yang menyangkut tata cara bermuamalat secara Islam. Tata cara bermuamalah yang dilakukan dengan menjauhi praktik-praktik yang dikhawatirkan mengandung unsur-unsur riba.

Berdasarkan Undang-Undang No. 10 Tahun 1998 Pasal 1 ayat 13, prinsip syariah adalah aturan perjanjian berdasarkan hukum Islam antara bank dan pihak lain untuk penyimpanan dana dan atau pembiayaan kegiatan usaha, atau kegiatan lainnya yang dinyatakan sesuai dengan syariah, antara lain pembiayaan berdasarkan prinsip bagi hasil (mudharabah), pembiayaan berdasarkan prinsip penyertaan modal (musyarakah), prinsip jual beli barang dengan memperoleh keuntungan (murabahah), atau pembiayaan barang modal berdasarkan prinsip sewa murni tanpa pilihan (ijarah). 


\subsection{Metode Pengukuran Efisiensi}

Pengukuran kinerja efisiensi perbankan dapat dilakukan dengan berbagai metode. Metode pengukuran efisiensi dapat dikelompokkan atas dua kategori utama yaitu metode parametrik dan non-parametrik. Salah satu metode non-parametrik yang umum digunakan untuk mengetimasi skor efisiensi adalah Data Envelopment Analysis (DEA).

DEA menghasilkan skor efisiensi ekonomi absolut sebuah bank dengan menggunakan program matematis dari kombinasi input dan output suatu bank kemudian melakukan generalisasi. Skor efisiensi berkisar dari 0 sampai 1, semakin mendekati 1 maka semakin efisien kinerja dari bank tersebut (Ada dan Dalkinic 2014). Secara khusus, DEA merupakan pengembangan teknik pemograman linier yang didalamnya terdapat fungsi tujuan dan fungsi kendala. Persamaan umum pada DEA adalah:

$$
\mathrm{h}_{\mathrm{s}}=\frac{\sum_{i=1}^{m} u_{i s} y_{i s}}{\sum_{j=1}^{n} v_{j s} x_{j s}}
$$

dimana $h_{s}$ menunjukkan efisiensi teknis BUS dan UUS ke-s; $u_{i s}$ menunjukkan bobot output i yang dihasilkan BUS dan UUS ke-s; $\mathrm{y}_{\text {is }}$ adalah bobot output i yang diproduksi pada BUS dan UUS ke-s; $\mathrm{v}_{\mathrm{js}}$ adalah bobot input $\mathrm{j}$ pada BUS dan UUS ke-s; dan $\mathrm{x}_{\mathrm{js}}=$ jumlah input $\mathrm{j}$ yang diberikan oleh BUS dan UUS ke-s.

Permasalahan yang terjadi pada persamaan (1) adalah adanya solusi persamaan dengan jumlah tidak terbatas (infinite). Nilai skor efisiensi berkisar antara 0-1, untuk menghasilkan solusi yang unik, dirumuskanlah sebuah fungsi kendala sebagai berikut:

$$
\mathrm{h}_{\mathrm{s}}=\frac{\sum_{i=1}^{m} u_{i s} y_{i s}}{\sum_{j=1}^{n} v_{j s} x_{j s}} \leq 1 ; \mathrm{r}=1,2, \ldots, \mathrm{N} \text { dan ui, yj } \geq 0
$$

dimana N menunjukkan jumlah BUS dan UUS dalam sampel. Persamaan (2) menunjukkan bahwa skor efisiensi bernilai positif dengan nilai maksimal 1 (satu). BUS dan UUS dapat dikatakan beroperasi efisien secara teknis saat skor efisiensi teknis yang dihasilkan 1 (satu). Sebaliknya, jika skor efisiensi teknis bernilai 0 (nol) maka BUS dan UUS dinilai tidak efisien. Pada DEA, setiap BUS dan UUS dapat menentukan pembobotnya masing-masing dan menjamin bahwa pembobot yang dipilih akan menghasilkan ukuran kinerja terbaik (Firdaus dan Hosen 2013).

\section{Constant Return to Scale (CRS)}

Ada dua model yang sering digunakan dalam pendekatan DEA, yaitu model CCR (1978) dan model BCC (1984). Metode DEA pertama kali diperkenalkan oleh Charnes, Cooper, dan Rhodes pada tahun 1978. Model ini mengasumsikan bahwa rasio antara penambahan input dan 
output adalah sama (constant return to scale). Artinya, jika ada tambahan input sebesar x kali, maka output akan meningkat sebesar x kali juga. Asumsi lain yang digunakan dalam model ini adalah bahwa setiap DMU beroperasi pada skala yang optimal. Berikut adalah persamaan pada model CRS:

$$
\begin{array}{ll}
\text { Max. } & \mathrm{h}_{\mathrm{s}}=\sum_{i=1}^{m} u_{i} y_{i s} \\
\text { St. } & \sum_{i=1}^{m} u_{i} y_{i r}-\sum_{j=1}^{m} v_{j} x_{j r} \leq 0 \quad ; \mathrm{r}=1, \ldots, \mathrm{N} \\
& \sum_{i=1}^{m} v_{j} x_{j s}=1, \ldots, \mathrm{n} \\
& \mathrm{v}_{\mathrm{i},} \mathrm{v}_{\mathrm{j}} \geq 0
\end{array}
$$

\section{Variabel Return to Scale (VRS)}

Sehubungan dengan kelemahan asumsi model CRS, muncul asumsi alternative model variable return to scale (VRS) atau disebut juga model BCC. Model ini beranggapan bahwa perusahaan tidak atau belum beroperasi pada skala yang optimal. Pada model ini, BUS dan UUS diasumsikan tidak memiliki kondisi internal dan eksternal yang sama serta tidak beroperasi pada persaingan sempurna. Asumsi dari model ini adalah bahwa rasio antara penambahan input dan output tidak sama (variable return to scale). Artinya, penambahan input sebesar x kali tidak akan menyebabkan penambahan output x kali, bisa lebih kecil atau lebih besar dari x kali (Ascarya dan Yumanita 2005). Perumusan matematis model VRS diperoleh dari pengembangan persamaan (3) dengan menambahkan kendala konektivitas (convexity constraint) berupa penggal yang dapat bernilai positif maupun negatif $\left(\cup_{0}\right)$ ke dalam persamaan sehingga rumus matematisnya menjadi:

$$
\begin{array}{ll}
\text { Max. } & \mathrm{h}_{\mathrm{s}}=\sum_{i=1}^{m} u_{i} y_{i s}+\mathrm{U}_{0} \\
\text { St. } & \sum_{i=1}^{m} u_{i} y_{i r}-\sum_{j=1}^{m} v_{j} x_{j r} \leq 0 \quad ; \mathrm{r}=1, \ldots, \mathrm{N} \\
& \sum_{i=1}^{m} v_{j} x_{j s}=1 \\
\mathrm{u}_{\mathrm{i}}, \mathrm{v}_{\mathrm{j}} \geq 0 &
\end{array}
$$

\subsection{Kajian Terdahulu mengenai Determinan Efisiensi Bank}

Beberapa penelitian mengenai efisiensi suatu perusahaan khususnya pada industri perbankan telah banyak dilakukan. Sufian (2007) melakukan studi mengenai analisis efisiensi bank syariah baik asing maupun domestik di Malaysia selama 2001-2004 menggunakan metode DEA. Variabel input yang digunakan antara lain total simpanan, biaya tenaga kerja, dan aset. Sedangkan variabel outputnya ialah pembiayaan dan pendapatan operasional. Hasil penelitian ini menyatakan bahwa secara keseluruhan efisiensi bank syariah di Malaysia mengalami peningkatan. Penelitian ini mengungkapkan bahwa bank asing syariah sedikit lebih rendah efisiensinya dibandingkan bank domestik syariah selama tahun pengamatan. 
Penelitian yang dilakukan oleh Yudistiara (2003) terhadap 18 bank syariah di seluruh dunia selama periode 1997-2000 dengan menggunakan pendekatan DEA dan spesifikasi input-output berdasarkan pendekatan intermediasi. Hasil penelitian menunjukkan keseluruhan efisiensi 18 bank syariah yang diteliti mengalami sedikit inefisiensi pada tingkat wajar 10 persen jika dibandingkan dengan bank konvensional. Hal ini disebabkan karena periode 1998-1999 bank-bank tersebut mengalami krisis global sehingga mempengaruhi kinerjanya. Studi juga menunjukkan bank syariah yang berskala kecil dan menengah cenderung tidak ekonomis. Bank syariah di kawasan Timur Tengah cenderung tidak efisien dibandingkan negara lainnya. Market power yang dimiliki Timur Tengah tidak berpengaruh terhadap efisiensi. Bank syariah di luar Timur Tengah relatif masih baru dan sangat didukung oleh kebijakan pemerintahnya. Selain itu, bank syariah yang sudah go public cenderung kurang efisien dibandingkan yang belum go public.

Mokhtar et al. (2008) mengukur dan menganalisis efisiensi bank syariah di Malaysia selama dan setelah krisis ekonomi (1997-2003). Penelitian ini menggunakan metode analisis DEA. Selama periode pengamatan, rata-rata efisiensi bank syariah di Malaysia secara menyeluruh tetap mengalami peningkatan. Studi ini menggambarkan bahwa rata-rata efisiensi bank umum syariah (BUS) relatif lebih baik dibandingkan bank konvensional yang membuka layanan Unit Usaha Syariah (UUS). Akan tetapi masih kurang efisien dibandingkan bank konvensional. Selain itu, bank asing juga dinilai lebih efisien dibandingkan bank domestik.

Chansarn (2008) melakukan penelitian mengenai tingkat efisiensi pada bank komersial di Thailand selama 2003-2006. Hasil penelitian menunjukkan bahwa tingkat efisiensi bank komersial di Thailand bersifat stabil dan sangat tinggi dengan rata-rata 90 persen setiap tahunnya dalam periode penelitian. Dengan menggunakan pendekatan intermediasi, bank-bank dengan skala kecil adalah yang paling efisien. Selain itu, pemain lama bank komersial dan pemain baru yang sebelumnya eksis di bidang keuangan dan sekuritas juga sudah efisien melalui pendekatan operasi dengan efisiensi rata-rata 100\%. Akan tetapi, secara rata-rata pemain lama lebih efisien dibandingkan pemain baru jika dilihat dari perspektif pendekatan intermediasi.

Noor et al. (2010) melakukan studi mengenai efisiensi perbankan syariah di negara Asia. Penelitian ini menggunakan metode DEA dengan periode penelitian tahun 2001 hingga 2006. Hasil studi menunjukkan inefisiensi teknis murni melebihi inefisiensi skala di sektor perbankan syariah. Hal ini mengindikasikan bahwa bank syariah tidak memanfaatkan sumber daya mereka secara efisien. Bank-bank Indonesia menjadi yang paling efisien di kawasan Asia, diikuti oleh bank dari Pakistan dan Bangladesh. Perbankan syariah di Malaysia paling tidak efisien.

Studi yang dilakukan oleh Muharam dan Puspitasari (2007) mengukur dan menganalisis efisiensi bank syariah di Indonesia pada tahun 2005. Hasil penelitian didapatkan bahwa dari dua belas yang diteliti, hanya ada tiga bank yang mencapai efisiensi 100 persen (BTN Syariah, Bank Niaga Syariah, dan Bank Permata Syariah). Sembilan bank lainnya dalam sampel mengalami fluktuasi dalam pencapaian tingkat efisiensi sepanjang tahun 2005. 
Studi yang dilakukan Jackson dan Fethi (2000) mengenai evaluasi efisiensi teknis perbankan Turki dengan metode DEA dan analisis Tobit pada tahun 1998. Variabel yang digunakan untuk mengetahui determinan tingkat efisiensi antara lain ukuran bank, jumlah cabang, profitabilitas, kepemilikan, dan rasio kecukupan modal. Hasil penelitian menunjukkan bank yang lebih besar dan memiliki profitabilitas yang lebih baik akan beroperasi pada tingkat efisisensi teknis yang lebih tinggi. Temuan lain menunjukkan bahwa rasio kecukupan modal berdampak negatif dan signifikan yang mencerminkan a risk-return tradeoff dalam sector perbankan. Selain itu, jumlah cabang yang menjadi proksi kedua untuk ukuran bank tidak berpengaruh secara signifikan dan berkorelasi negatif pada efisiensi. Variabel kepemilikan berkorelasi negatif dan tidak signifikan. Meskipun tidak berpengaruh secara statistik, studi ini menunjukkan bahwa bank negara kurang efisien dibandingkan dengan bank lainnya.

Endri (2010) melakukan studi mengenai evaluasi terhadap kinerja efisiensi teknis perbankan syariah di Indonesia selama periode 2008-2010 menggunakan two-stage data envelopment analysis. Hasil pengujian tahap kedua menggunakan metode Tobit menunjukkan bahwa faktor total asset, jenis bank, net operating income, dan kualitas pembiayaan memiliki pengaruh positif tetapi tidak signifikan. Sementara koefisien kecukupan modal memiliki pengaruh negatif tetapi juga tidak signifikan.

Penelitian yang dilakukan oleh Firdaus dan Hosen (2013) mengenai efisiensi bank umum syariah menggunakan pendekatan Two-Stage Data Envelopment Analysis menunjukkan bahwa perkembangan tingkat efisiensi sepuluh Bank Umum Syariah mempunyai trend yang fluktuatif dikarenakan tingkat efisiensi BUS secara individu juga bersifat fluktuatif. Berdasarkan hasil pengukuran efisiensi, BUS yang terlebih dahulu berdiri seperti Bank Muamalat Indonesia dan Bank Syariah Mandiri memiliki tingkat efisiensi rata-rata yang sangat baik bila dibandingkan dengan BUS lainnya yang baru berdiri. Dengan hasil pengukuran ini dapat disimpulkan bahwa Bank Umum Syariah di Indonesia masih dikategorikan inefisien atau belum optimal dalam mengelola sumber daya yang dimilikinya. Tahapan kedua dalam penelitian ini menggunakan model Tobit menunjukkan variabel ROA dan ROE yang mewakili tingkat profitabilitas suatu bank berpengaruh positif dan signifikan terhadap efisiensi bank. Sedangkan variabel NPF yang menunjukkan adanya pengaruh negatif dan signifikan. Hal tersebut dikarenakan semakin besar rasio pembiayaan macet pada suatu bank, maka secara otomatis menganggu kegiatan operasional bank yang menyebabkan inefisiensi.

Penelitian yang dilakukan oleh Zamil (2007) mengenai perbandingan efisiensi antara perbankan konvensional dan perbankan syariah di Malayasia dari tahun 2000 hingga 2004 menggunakan metode DEA dan uji regresi linier. Hasil penelitian menunjukkan bahwa sumber utama efisiensi di Malaysia adalah efisiensi teknis. Secara umum, rata-rata mayoritas bank lebih efisien dengan menggunakan asumsi VRS. Manajemen dan operasional bank konvensional di Malaysia lebih efisien dibandingkan dengan bank syariah. Hasil estimasi regresi linier menunjukkan bahwa ukuran bank memiliki pengaruh positif secara signifikan terhadap tingkat 
efisiensi, baik dari sisi efisiensi teknis maupun efisiensi skala. Permodalan bank juga memiliki hubungan negatif secara signifikan dengan pure technical efficiency (PTE).

Penelitian mengenai kajian efisiensi perbankan syariah di Indonesia menggunakan pendekatan Data Envelopment Analysis juga dilakukan oleh Hidayat (2011). Hasil studi menunjukkan bahwa jumlah bank yang efisien berbeda menurut kedua pendekatan efisiensi teknik. Untuk pendekatan efisiensi teknik Constant Return to Scale (CRS), bank yang efisien sangat sedikit bila dibandingkan dengan yang tidak efisien. Sedangkan pendekatan efisiensi teknik Variable Return to Scale (VRS), bank yang efisien lebih banyak bila dibandingkan dengan bank yang tidak efisien. Selain itu, hasil penelitian ini juga menunjukkan bahwa mayoritas perbankan dari kelompok BUS memiliki tingkat efisiensi lebih tinggi dibandingkan kelompok UUS.

Lutfiana dan Yulianto (2015) menganalisis tingkat efisiensi BUS dan menganalisis pengaruh kinerja keuangan yang diproksikan dengan ROE, CAR, NPF, PPAP, BOPO, FDR, dan cabang bank terhadap tingkat efisiensi. Hasil penelitian menunjukkan bahwa CAR berpengaruh positif dan signifikan terhadap tingkat efisiensi dan BOPO berpengaruh negatif dan signifikan terhadap efisiensi. Dilain pihak, ROE, NPF, PPAP, FDR, dan cabang bank tidak berpengaruh signifikan terhadap tingkat efisiensi.

Widiarti (2015) melakukan penelitian mengenai determinan efisiensi dan profitabilitas perbankan di Indonesia. Hasil penelitian menunjukkan bahwa bank umum konvensional pada periode Q1 2012 hingga Q4 2014 belum sepenuhnya efisien. Faktor internal yang berpengaruh negatif dan signifikan terhadap efisiensi yang diukur dengan DEA adalah NPL, LDR, CER, dan komposisi deposito terhadap DPK, sedangkan yang berpengaruh positif adalah CAR dan NIM. Faktor internal yang tidak berpengaruh terhadap efisiensi adalah nilai GCG. Selain itu, analisis data panel yang dilakukan untuk mengetahui faktor-faktor internal bank yang memengaruhi profitabilitas menunjukkan bahwa ukuran bank, tipe bank, dan NIM berpengaruh positif dan signifikan terhadap ROA. Disisi lain, NPL, CAR, LDR, BOPO, komposisi deposito terhadap DPK, dan nilai GCG berpengaruh negatif dan signifikan.

Studi mengenai determinan dan dampaknya terhadap profitabilitas industri perbankan di Indonesia dilakukan oleh Subandi dan Ghozali (2013). Hasil penelitian menunjukkan variabel yang paling dominan memengaruhi tingkat efisiensi teknis dan dampaknya terhadap profitabilitas perbankan konvensional adalah jenis bank, sedangkan yang paling lemah pengaruhnya adalah LDR. Variable tipe bank membuktikan bahwa tingkat efisiensi teknis DEA dan kinerja profitabilitas ROA bank asing lebih baik dibandingkan bank domestic. Untuk itu bank domestik dapat menjadikan bank asing sebagai benchmarking dalam meningkatkan tingkat efisiensi dan kinerja profitabilitasnya. 


\section{METODOLOGI}

\subsection{Jenis dan Sumber Data}

Data yang digunakan dalam penelitian ini adalah data sekunder, dimana sampel yang digunakan yakni 10 BUS dan 15 UUS pada periode Q2 2014 hingga Q2 2016. Data sekunder diperoleh dari laporan keuangan, hasil penelitian terdahulu, dan literatur pada berbagai lembaga atau instansi terkait.

Data sekunder yang dikumpulkan, mencakup ukuran perusahaan (size), simpanan wadiah, pembiayaan, CAR, dan FDR. Data-data ini diperoleh dari laporan keuangan triwulanan yang dikeluarkan oleh masing-masing perusahaan.

\subsection{Teknik Analisis Data}

\section{Metode Data Envelopment Analysis (DEA)}

Metode DEA menghitung efisiensi teknis untuk seluruh unit. Penelitian ini akan menggunakan alat bantu software MaxDea untuk menghitung tingkat efisiensi. Nilai efisiensi BUS dan UUS diukur dengan metode DEA menggunakan pendekatan intermediasi dengan asumsi variable return to scale (VRS) dengan pengukuran berorientasi input dan output. Alasan pemilihan skala efisiensi model VRS ini adalah studi ini ingin mengetahui tingkat efisiensi sebenarnya (tanpa dibatasi oleh kendala apapun). Adapun variabel input dan output yang digunakan dalam penelitian ini dapat dilihat pada Tabel 2.

\begin{tabular}{|c|c|c|}
\hline \multicolumn{3}{|r|}{$\begin{array}{c}\text { Tabel } 2 . \\
\text { Variabel input-output Penelitian }\end{array}$} \\
\hline Variabel Input & Sumber Data & Literatur \\
\hline Dana pihak ketiga & Neraca & Mokhtar et al. (2008), Yudistiara (2003) \\
\hline Aktiva tetap & Neraca & Yudistiara (2003), Widiarti (2015) \\
\hline Biaya tenaga kerja & Laba rugi & Sufian (2007), Yudistiara (2003) \\
\hline Variabel Output & Sumber Data & Literatur \\
\hline Pembiayaan & Neraca & Suseno (2008), Noor et al. (2010), Pratikto dan Sugianto (2011) \\
\hline $\begin{array}{l}\text { Pendapatan } \\
\text { operasional }\end{array}$ & Laba rugi & Sufian (2007), Praktiko dan Sugianto (2011) \\
\hline
\end{tabular}

\section{Analisis Regresi Data Panel}

Analisis regresi data panel digunakan untuk melihat faktor-faktor yang memengaruhi tingkat efisiensi BUS dan UUS yang sebelumnya telah didapatkan melalui metode DEA.

$$
\begin{aligned}
& \text { EFISIENSI }_{\mathrm{it}}=\alpha+\beta_{1} \operatorname{InSIZE}_{\mathrm{it}}+\beta_{2} \operatorname{InPembiayaan}{ }_{\mathrm{it}}+\beta_{3} \operatorname{lnS} \text { wadiah }_{\mathrm{it}}+\beta_{4} \mathrm{CAR}_{\mathrm{it}}+\beta_{5} \mathrm{FDR}_{\mathrm{it}} \\
& +\varepsilon_{\mathrm{it}} ; i=1,2, \ldots \mathrm{N} ; \mathrm{t}=1,2, \ldots \mathrm{n}
\end{aligned}
$$


Variabel dependen yaitu efisiensi, sedangkan variabel independen meliputi total asset (Size), total pembiayaan, total dana simpanan wadiah, Capital Adequacy Ratio (CAR), dan Financing Deposit Ratio (FDR),

\section{HASIL DAN ANALISIS}

\subsection{Hasil Pengukuran Efisiensi Bank dengan Menggunakan Metode DEA}

Hasil pengukuran nilai efisiensi dengan metode DEA berkisar antara 0 sampai dengan 1. Mansyur (2012) menyatakan efisiensi bernilai 1 atau 100\% menunjukkan bahwa bank tersebut paling efisien dalam sampel pada periode tertentu, sedangkan nilai efisiensi bank lainnya relatif terhadap bank yang lebih efisien tersebut.

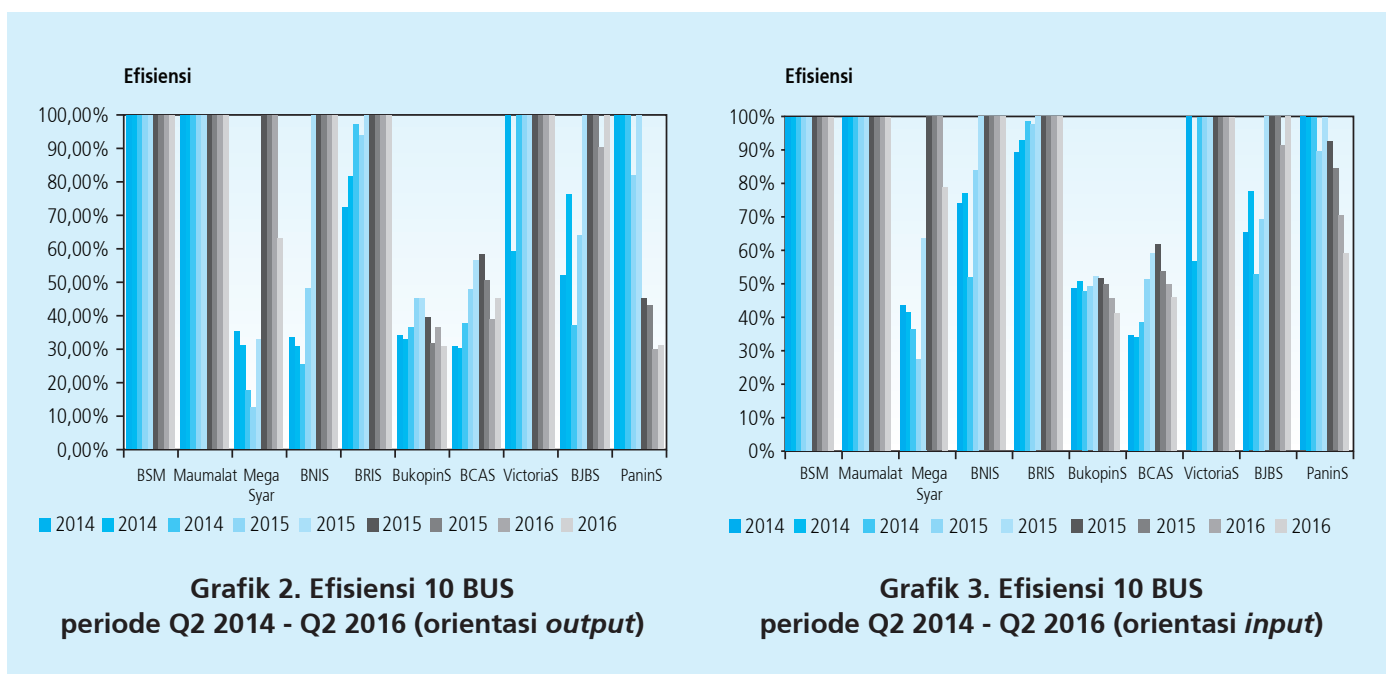

Grafik 2 dan 3 menunjukkan hasil pengukuran tingkat efisiensi BUS dengan orientasi output dan input periode Q2 2014 - Q2 2016. Hasil pengukuran dengan kedua orientasi tersebut tidak jauh berbeda. BSM dan Muamalat memiliki efisiensi sempurna selama periode penelitian. Bank Mega Syariah dan BCAS mengalami fluktuatif efisiensi selama periode penelitian. Selain itu, Bank Bukopin Syariah, BCAS, Panin Syariah, dan Mega Syariah mengalami tren menurun hingga Q2 2016.

Grafik 4 dan 5 menunjukkan hasil pengukuran tingkat efisiensi UUS dengan orientasi output dan orientasi input periode Q2 2014 - Q2 2016. Mayoritas BPD syariah memiliki efisiensi yang lebih rendah dibandingkan bank konvensional yang membuka Unit Usaha Syariah. Selain itu BPD syariah seperti DKI Syariah, Kalsel Syariah, Sumsel Syariah, Sumut Syariah, Kaltim Syariah, dan Riau Syariah memiliki tingkat efisiensi yang berfluktuatif selama periode 
penelitian. Terdapat 4 UUS yang memiliki efisisiensi sempurna selama peiode penelitan, yaitu Permata Syariah, BII Syariah, OCBC Syariah, dan Yogya Syariah. Bank Kalimantan Barat Syariah mengalami penurunan yang signifikan saat periode Q1 2015 baik dengan pengukuran yang berorientasi output maupun input.

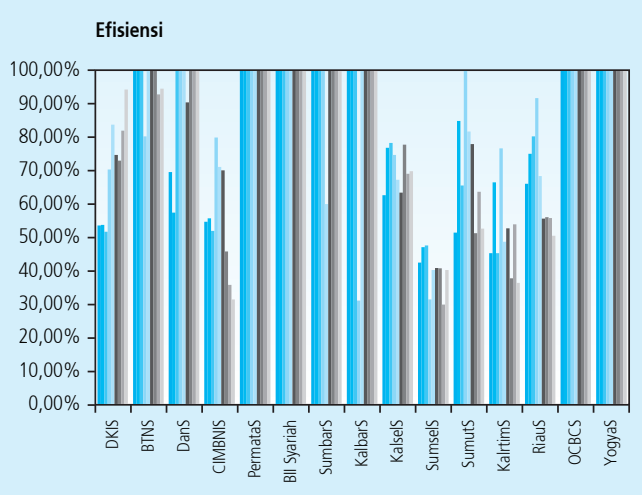

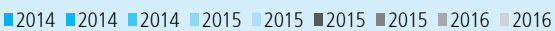

Grafik 4. Efisiensi 15 BUS periode Q2 2014 - Q2 2016 (orientasi output)

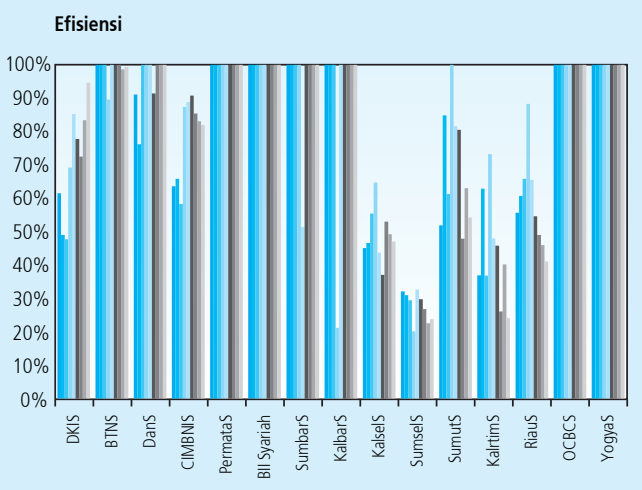

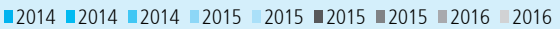

Grafik 5. Efisiensi 15 BUS periode Q2 2014 - Q2 2016 (orientasi input)

Pencapaian tingkat efisiensi rata-rata pada masing-masing bank syariah, baik BUS maupun UUS dengan orientasi output dan orientasi input selama periode penelitian dapat dilihat pada Grafik 6 dan Grafik 7. Terdapat enam bank syariah yang memiliki efisiensi rata-rata sempurna selama periode penelitian, antara lain BSM, Muamalat, Permata Syariah, BII Syariah, OCBC Syariah, dan Yogya Syariah.

Pada pengukuran yang berorientasi output terdapat satu BUS dan dua BUS yang memiliki efisiensi rata-rata dibawah 75 dan 50 persen. Disisi lain, terdapat tiga UUS dengan orientasi output yang masing-masing memiliki efisiensi dibawah 75 dan 50 persen. Dengan menggunakan pengukuran yang berorientasi input, terdapat tiga BUS dan dua BUS yang memiliki efisiensi rata-rata dibawah 75 dan 50 persen. Selain itu terdapat enam UUS dan satu UUS yang memiliki efisiensi dibawah 75 dan 50 persen. 


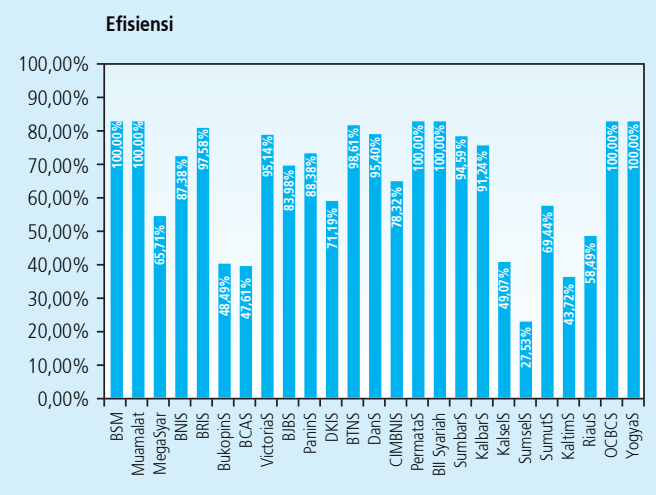

Grafik 6. Efisiensi Rata-rata BUS dan UUS periode Q2 2014-Q2 2016 (orientasi output)
Efisiensi

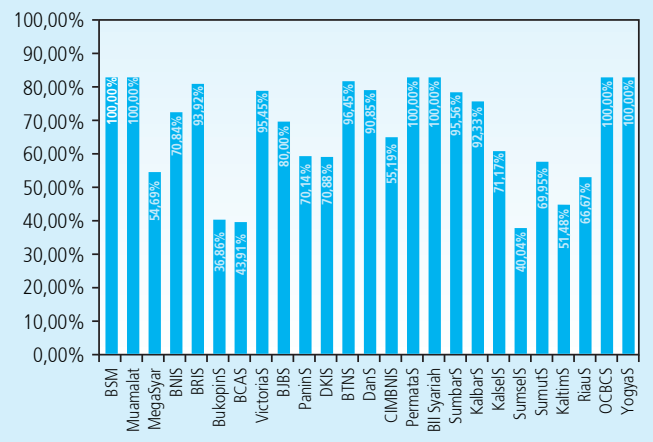

Grafik 7. Efisiensi Rata-rata BUS dan UUS periode Q2 2014-Q2 2016 (orientasi input)

Berdasarkan hasil diatas, secara keseluruhan perkembangan tingkat efisiensi BUS dan UUS memiliki trend yang fluktuatif. Dengan hasil tersebut dapat disimpulkan bahwa BUS dan UUS di Indonesia dikategorikan inefisien atau belum optimal dalam mengelola sumber daya yang dimiliki. Hal ini sesuai dengan studi yang dilakukan oleh Endri (2010) dan Firdaus \& Hosen (2013).

\subsection{Faktor-faktor yang Memengaruhi Efisiensi BUS dan UUS}

Determinan efisiensi BUS dan UUS didapatkan dengan menggunakan regresi data panel. Pemilihan model terbaik pada penelitian ini didapat dari hasil Uji Chow dan Uji Hausman yang menunjukkan bahwa model terbaik yang digunakan adalah model efek tetap atau Fixed Effect Model (FEM). Adapun hasil regresi data panel model pada penelitian ini dapat dilihat pada Tabel 3.

Hasil regresi data panel menunjukkan bahwa variabel pembiayaan, simpanan wadiah, dan capital adequacy ratio (CAR) secara bersama-sama memberikan pengaruh yang signifikan terhadap efisiensi BUS dan UUS baik dengan pengukuran yang berorientasi output maupun input. Sedangkan variabel total aset (size) dan FDR secara bersama-sama tidak memberikan pengaruh yang signifikan terhadap efisiensi BUS dan UUS baik dengan pengukuran yang berorientasi output maupun input.

Hasil estimasi penelitian ini menunjukkan bahwa model dengan orientasi output memiliki nilai $R^{2}$ sebesar 82 persen. Artinya, goodness of fit dari model dapat dijelaskan sebesar 82 persen, sisanya sebesar 18 persen dijelaskan oleh faktor lain di luar model. Model dengan orientasi input memiliki nilai $\mathrm{R}^{2}$ sebesar 70.9 persen, sisanya sebesar 29.1 persen dijelaskan oleh faktor diluar model. Probabilistik F-statistik untuk kedua model efisiensi memiliki pengaruh signifikan 


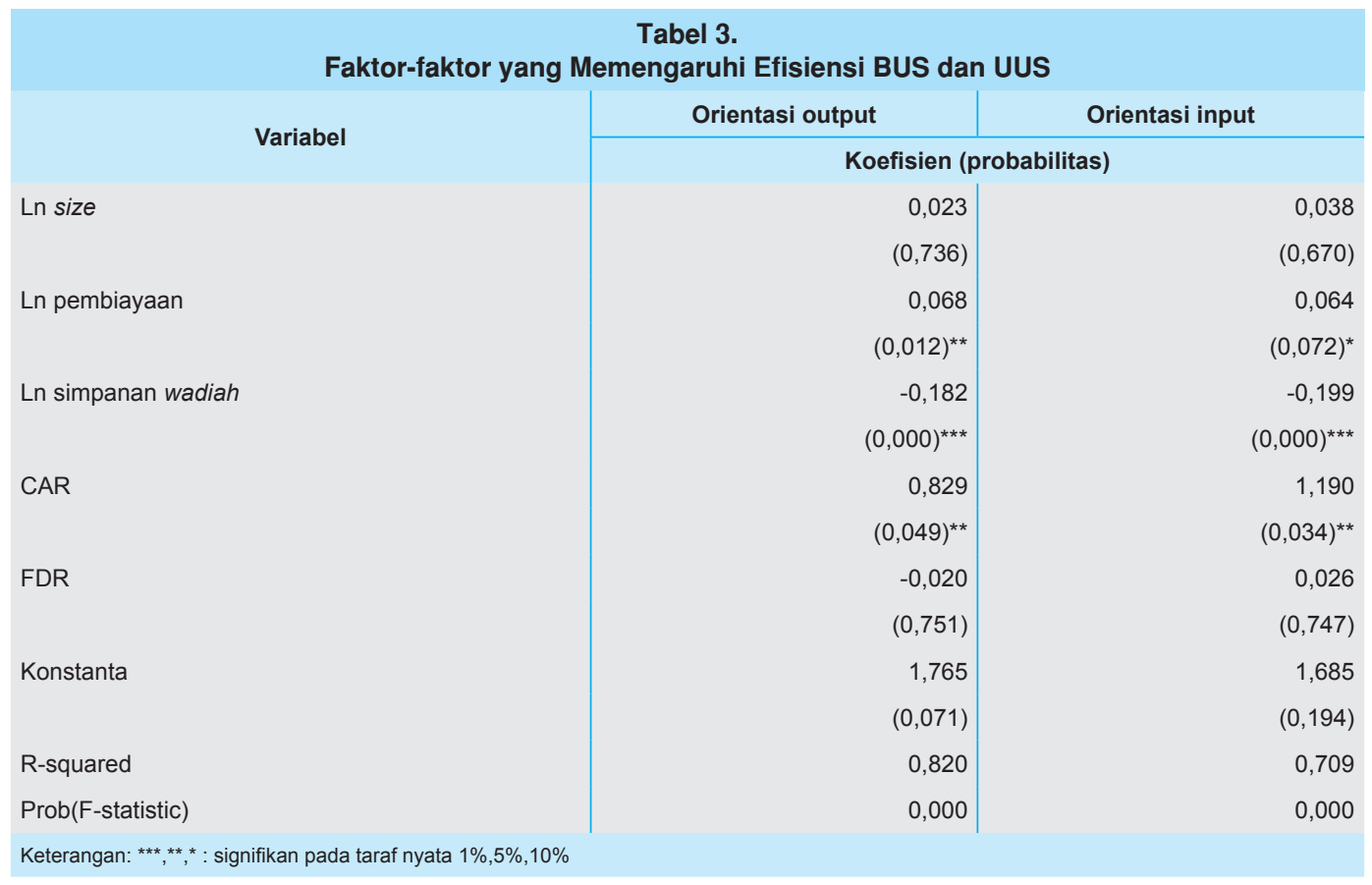

pada 0.000 , nilai ini lebih kecil dari nilai taraf nyata sebesar 0.10 atau 10 persen. Hal tersebut mengindikasikan bahwa secara keseluruhan semua variabel independen yang meliputi In size, In pembiayaan, In simpanan wadiah, CAR, dan FDR memiliki pengaruh terhadap variabel dependennya yaitu efisiensi BUS dan UUS.

Hasil estimasi model data panel membuktikan bahwa pembiayaan berpengaruh positif dan signifikan terhadap efisiensi teknis BUS dan UUS pada kedua model, yaitu orientasi output dan input dengan taraf nyata 5\% dan 10\%, ceteris paribus. Pembiayaan merupakan output yang dihasilkan BUS dan UUS. Peningkatan jumlah pembiayaan yang disalurkan akan meningkatkan efisiensi karena semakin besar pembiayaan yang disalurkan baik melalui akad mudharabah dan musyarakah, semakin optimal BUS dan UUS menjalankan fungsinya sebagai lembaga intermediasi sehingga semakin efisien BUS dan UUS. Menurut Isik dan Hassan (2003), hubungan positif antara pinjaman dan efisiensi perbankan dapat disebabkan oleh kemampuan bank yang dapat mengelola operasionalnya secara lebih produktif yang memungkinkan bank untuk memiliki biaya produksi yang lebih rendah, sehingga dapat memberikan syarat pinjaman yang lebih sederhana. Hal ini memungkinkan BUS dan UUS untuk mendapatkan pangsa pasar yang lebih besar pada segmen pembiayaan. Hasil penelitian ini sejalan dengan penelitian yang dilakukan oleh Sufian dan Noor (2009) dan Karimah (2016).

Berdasarkan hasil estimasi model data panel dinyatakan bahwa dana simpanan wadiah atau Dana Pihak Ketiga (DPK) berpengaruh negatif dan signifikan terhadap efisiensi teknis BUS 
dan UUS dengan kedua pengukuran kedua orientasi pada taraf nyata 1\%, ceteris paribus. Peningkatan (penurunan) dana simpanan wadiah akan menyebabkan penurunan (peningkatan) efisiensi teknis BUS dan UUS. Peningkatan dana simpanan wadiah akan menurunkan tingkat efisiensi teknis BUS dan UUS. Kondisi ini dapat disebabkan oleh biaya bagi hasil yang dikeluarkan oleh BUS dan UUS untuk nasabah yang menitipkan dananya. Semakin banyak simpanan wadiah yang diterima BUS dan UUS, semakin besar biaya bagi hasil yang akan menyebabkan menurunnya efisiensi teknis.

Secara konsep terdapat dua jenis akad wadiah yaitu wadiah amanah dan wadiah yadh dhamanah. Wadiah amanah adalah dana titipan yang hanya boleh disimpan, tidak boleh didayagunakan oleh penerima titipan. Wadiah yadh dhamanah adalah dana titipan yang boleh didayagunakan oleh penerima titipan dengan seizin pemilik dana dan dengan jaminan bahwa dana titipan tersebut dapat diambil oleh pemiliknya setiap saat. Hasil pendayagunaan dana wadiah yadh amanah tidak wajib dibagikan ke pemilik dana namun penerima dana boleh saja memberikan sebagian dari hasil pemberdayaan dana namun hal tersebut tidak boleh dijanjikan di awal akad (Nurhayati dan Wasilah 2013).

Dalam praktiknya, bank syariah menggunakan sistem profit loss sharing (PLS), nasabah yang bersifat risk averse akan memilih akad wadiah karena besarnya dana yang dititipkan tidak akan berkurang. Untuk meningkatkan jumlah nasabah, BUS dan UUS tetap memberikan bonus bagi nasabah yang menabung dengan akad wadiah. Oleh karena itu, semakin besar dana simpanan wadiah yang diterima BUS akan menyebabkan peningkatan biaya bonus sehingga tingkat efisiensi teknis akan menurun. Hasil penelitian ini sejalan dengan studi yang dilakukan oleh Sufian dan Noor (2009), Widiarti (2015), dan Karimah (2016).

CAR memengaruhi secara positif dan signifikan terhadap efisiensi teknis BUS dan UUS pada kedua model dengan taraf nyata $5 \%$, ceteris paribus. Setiap peningkatan (penurunan) CAR akan meningkatkan (menurunkan) efisiensi teknis BUS dan UUS. CAR merupakan rasio kecukupan modal yang nilainya didapatkan dari perbandingan antara modal dengan ATMR yaitu untuk mengukur kemampuan permodalan bank dalam menyerap potensi kerugian yang timbul dari risiko kredit, risiko suku bunga, dan risiko likuiditas. Jika modal bank diasumsikan tetap dan ATMR atau bobot resiko aktiva produktif bank tersebut meningkat, maka sebagai dampak dari kondisi tersebut ialah CAR bank akan turun. Peningkatan ATMR berpotensi meningkatkan risiko pembiayaan dan modal harus mampu menyerap potensi risiko tersebut. Ketika BUS dan UUS memiliki modal yang cukup, BUS dan UUS akan lebih mampu untuk menghadapi risiko di masa mendatang sehingga kinerjanya dinilai semakin efisien. Hasil ini ditemukan pula oleh Ramli (2005), Gupta et al. (2008), Subandi dan Ghozali (2013), Widiarti (2015), dan Karimah (2016). 


\section{Implikasi Manajerial}

Berdasarkan hasil penelitian yang telah dilakukan, industri perbankan syariah memerlukan dukungan penuh dari seluruh stakeholders, seperti manajemen bank syariah itu sendiri. Dengan demikian implikasi yang dapat diberikan untuk perbankan syariah di Indonesia sebagai berikut:

Salah satu yang perlu diperhatikan oleh manajemen bank terkait efisiensi BUS dan UUS adalah simpanan wadiah. Variabel simpanan wadiah memberikan pengaruh negatif terbesar terhadap efisiensi BUS dan UUS baik diukur dengan menggunakan pengukuran yang berorientasi output maupun input. Manajemen bank syariah harus menyusun kebijakan pengelolaan dana wadiah agar investasi yang dilakukan bank syariah produktif dan menguntungkan.

Manajemen bank syariah juga perlu meningkatkan pembiayaan yang disalurkan, dalam hal ini pembiayaan yang berasaskan bagi hasil, seperti mudharabah dan musyarakah. Variabel pembiayaan lebih besar pengaruhnya saat diukur dengan menggunakan pengukuran yang berorientasi output dibandingkan orientasi input. Hal ini menunjukkan bahwa semakin besar jumlah pembiayaan yang disalurkan, semakin besar efisien BUS dan UUS dalam menjalankan fungsinya sebagai lembaga intermediasi.

Manajemen bank syariah juga perlu meningkatkan kemampuan permodalan untuk mendukung efisiensi operasionalnya. BUS dan UUS yang telah memenuhi ketentuan permodalan diharapkan dapat menjalankan kegiatan usahanya secara efisien.

\section{KESIMPULAN}

Paper ini merupakan studi empiris atas tingkat efisiensi perbankan dan unit usaha Syariah di Indonesia. Dengan mempergunakan pendekatan Data Envelopmen Analysis (DEA) dan estimasi data panel, paper ini membeirkan 2 (dua) kesimpulan utama, pertama, Bank Umum Syariah (BUS) dan Usaha Unit Syariah (UUS) di Indonesia secara teknis belum sepenuhnya beroperasi secara efisien. Kedua, variabel pembiayaan dan CAR berpengaruh positif dan signifikan terhadap tingkat efisiensi BUS dan UUS. Ketiga, simpanan wadiah berpengaruh negatif dan signifikan terhadap efisiensi BUS dan UUS di Indonesia.

Penelitian ini memiliki beberapa keterbatasan dan dapat diperbaiki dalam penelitian berikutnya; yakni penambahan periode penelitian dalam menganalisis determinan efisiensi BUS dan UUS, dan yang kedua, perlunya memasukkan peer country dalam analisis. Ini termasuk negara-negara yang memiliki karakter cukup dekat dengan Indonesia misalnya negara-negara di Asia Tenggara. 


\section{DAFTAR PUSTAKA}

Abidin Z dan Cabanda E. 2007. Frontier Approaches to Production Efficiency of Commercial Banks in Indonesia. Majalah Usahawan Indonesia, No. 06

Ada AA, Dalkinic N. 2014. Efficiency Analysis in Islamic Banks: A Study For Malaysian and Turkey. BDDK Bankacilik ve Finansal Piyasalar, 8(1):19-33.

Antonio MS. 2001. Bank Syariah dari Teori ke Praktik. Jakarta (ID): Penerbit Gema Insani Press.

Ascarya dan Yumanita D. 2005. Bank Syariah: Gambaran Umum, Pusat Pendidikan dan Studi Kebanksentralan (PPSK). Jakarta(ID): Bank Indonesia.

Berger AN, Humphrey DB. 1992. Measurement and Efficiency Issues in Commercial Banking. National Bureau of Economic Research, p. 245-300

Chansarn S. 2008. The Relative Efficiency of Commercial Banks in Thailand. International Research Journal of Finance and Economics, 53-68.

Endri. 2010. Evaluasi Efisiensi Teknis Perbankan Syariah di Indonesia: Aplikasi Two-Stage Data Envelopment Analysis. Finance and Banking Journal. STEI TAZKIA.

Firdaus dan Hosen. 2013. Efisiensi Bank Umum Syariah Menggunakan Pendekatan Two-Stage Data Envelopment Analysis. Buletin Ekonomi Moneter dan Perbankan, 16 (2): 155-176.

Gupta OK, Doshit Y, Chinubhai A. 2008. Dynamics of Productive Efficiency of Indian Banks. International Journal of Operations Research. 5(2): 78-90. Finance and Economics. USA. $1(1): 1-22$.

Hadad MD, Wimboh S, Dhaniel I, Eugenia M. 2003. Pendekatan Parametrik Untuk Efisiensi Perbankan Indonesia. Research Paper. No 4/5. Biro Stabilitas Sistem Keuangan Bank Indonesia.

Hassan MK. 2006. The X-Efficiency in Islamic Banks. Islamic Economic Studies, 13(2).

Hidayat HR. 2011. Kajian Efisiensi Perbankan Syariah di Indonesia (Pendekatan Data Envelopment Analysis). Media Riset Bisnis \& Manajemen, 1-19.

Isik, I dan Hassan MK. 2003. Efficiency, Ownership, and Market Structure, Corporate Control and Governance in the Turkish Banking Industry. Journal of Business Finance \& Accounting, 30(9\&10): 1363-1421.

Jackson PM, Fethi MD. 2000. Evaluating the Technical Efficiency of Turkish Commercial Bank: An Application of DEA and Tobit Analysis. ResearchGate. University of Leicester, 18. 
Karimah S. 2016. Kajian Efisiensi Bank Umum Syariah di Indonesia dan Faktor-faktor yang Memengaruhinya. [Tesis]. Bogor(ID): Institut Pertanian Bogor.

Lutfiana RH, Yulianto A. 2015. Determinan Tingkat Efisiensi Bank Umum Syariah di Indonesia (Pendekatan Two Stage DEA). Accounting Analysis Journal, 4(3).

Mansyur F. 2012. Analisis Perbandingan Efisiensi Bank Umum Syariah dan Bank Umum Konvensional di Indonesia Menggunakan Metode Stochastic Frontier Approach (SFA). [Tesis]. Yogyakarta (ID): UIN Sunan Kalijaga Yogyakarta.

Mokhtar HSA, Abdullah N, Alhabshi SM. 2008. Efficiency and Competition of Islamic Banking in Malaysia. Journal Humanomics, 24 (1): 28-48. Emerald: Group Publishing Limited.

Muharam H, Pusvitasari R. 2007. Analisis Perbandingan Efisiensi Bank Syariah di Indonesia dengan Metode Data Envelopment Analysis (periode tahun 2005). Jurnal Ekonomi Islam, 2 (3): $13-26$.

Noor MANM, Ahmad NH, Sufian F. 2010. The Efficiency of Islamic Banks: Empirical Evidence from the Asian Countries Islamic Banking Sectors. MPRA. Inderscience Enterprises Ltd.

Nurhayati S, Wasilah. 2013. Akutansi Syariah di Indonesia: Edisi 3. Jakarta(ID): Salemba Empat.

Pratikto H, Sugianto I. 2011. Kinerja Efisiensi Bank Syariah Sebelum dan Sesudah Krisis Global berdasarkan Data Envelopment Analysis (DEA). Jurnal Ekonomi Bisnis, 16 (2).

Ramli M. Studi tentang Tingkat Efisiensi Bank Komersial di Indonesia dan Beberapa Faktor Penentu. [Disertasi]. Depok(ID): Universitas Indonesia.

Subandi, Ghozali I. 2013. Determinan Efisiensi dan Dampaknya terhadap Kinerja Profitabilitas Industri Perbankan Indonesia. Jurnal Keuangan dan Perbankan, 17 (1): 123-135.

Sufian F. 2007. The Efficiency of Islamic Banking Industry in Malaysia: Foreign Versus Domestic Banks. Paper INCEIF Colloquium. Malaysia.

Sufian F, Noor Mohammad AMN. 2009. The Determinants of Islamic Bank Efficiency Changes: Empirical Evidence from the MENA and Asian Banking Sectors. Journal the Middle East Business and Economic Review, 20 (1): 179-200.

Suseno P. 2008. Analisis Efisiensi dan Skala Ekonomi pada Industri Perbankan Syariah di Indonesia. Jurnal Ekonomi Islam. 2 (1). Yogyakarta (ID): Pusat Pengkajian dan Pengembangan Ekonomi Islam (P3EI) Fakultas Ekonomi UII.

Wheelock DC dan Wilson PW. 1999. Technical Progress Inefficiency and Productivity Change in U.S. Banking. 1984-1993. Journal of Money, Credit, and Banking, 31(2). 
Widiarti AW. 2015. Determinan Efisiensi dan Profitabilitas Perbankan di Indonesia. [Tesis]. Bogor (ID): Institut Pertanian Bogor.

Yudistiara D. 2003. Efficiency in Islamic Banking: An Empirical Analysis of 18 Banks. Paper Loughborough University, United Kingdom.

Zamil NAM. 2007. Efficiency of Islamic and Conventional Commercial Banks in Malaysia: A Data Envelopment Analysis (DEA) Study. [Disertasi]. Malaysia: International Islamic University Malaysia (IIUM). 
Halaman ini sengaja dikosongkan 